\title{
Assessing the performance of social spending in Europe
}

\begin{abstract}
Based on the construction of a composite index to assess the relative performance of welfare policies, we show that the variability of performances cannot be explained only by the amount of resources devoted to social policies, but also by its composition: countries with higher shares of social public expenditure, specifically aimed at reducing income concentration, obtain better results. This associates the traditional classification of the European welfare systems to the performance obtained in the social sector.
\end{abstract}

KEYWORDS: welfare policies; social expenditure; social performance index; European Union

RECEIVED 7 April 2017; ACCEPTED 21 November 2017.

\section{INTRODUCTION}

The effectiveness of national social policies in Europe has been the subject of political and theoretical debates in the context of the economic crisis, population ageing and intervention at the Union level through the European guidelines (Bouget, 2003; Ferrera, 2009; Caminada et al., 2010; van Vliet, 2010) as, for example, pension reforms and the extension of the provision of early childhood services aimed at reconciling work and family.

The economic literature has associated the type of welfare system with the degree of achievement of policy objectives (Titmuss, 1974; Esping-Andersen, 1990; Rhodes 1996; Goodin et al, 1999; Bertola et al, 2001; Arts and Gelissen 2002; Zoli 2004; Ferrera, 1996 and 2012, Ferrera et al, 2000; Hudson and Kuhner, 2012; Joumard et al., 2012; Minas et al., 2014).

Existing contributions, however, mainly perform sectoral analyses. For instance, in the Mediterranean countries, lower social expenditure to reconcile work and family is associated with lower female participation in the labour market. However, disaggregated analyses cannot provide an assessment of the overall national social policies, since a given sectoral policy can have cross-effects on other areas. For instance, a higher expenditure level in the support of families (e.g., childcare) encourages female participation in the labour market, and can therefore contribute to reduce poverty and income inequality.

Against this background, the aim of this paper is to construct an aggregate indicator of social protection performance, that summarizes the output achieved in all the sectors of social protection, as specified in the OECD Social Expenditure Database (SOCX): family, health, labour market, elderly, disabled, unemployment, and inequality; as a second step, we investigate the variables that are correlated with the degree of achievement of social objectives, proposing, as an avenue for future research, the analysis of the composition of social expenditure as a determinant of the performance of social policy.

For this purpose, we identify the outcome indicators for each area of social expenditure. Then, following the methodology proposed by Tanzi and Schuknecht (2000) and Afonso et al. (2005, 2006), we construct a composite performance index for the social sector and relate it to the net social expenditure (i.e., the social expenditure net of the national fiscal measures as tax levies and benefits).

Our analysis shows that the variability of performances cannot be explained only by the amount of resources invested in social protection. In other terms, a general strong positive correlation between performance and social expenditure level doesn't exist. A stronger correlation can be identified only for the subgroups of countries.

However, we find some evidence that the performance level can be related to the composition of social expenditure: the countries characterized by high shares of public expenditure specifically aimed at reducing the income concentration obtain better overall

1 M. Alessandra Antonelli: Sapienza University of Rome, School of Law. Email: alessandra.antonelli@uniroma1.it; Valeria De Bonis: Sapienza University of Rome, School of Law. E-mail: valeria.debonis@uniroma1.it. We thank the Editor and two anonymous Referees for helpful comments and suggestions. The usual disclaimers apply. 
results in the social sector. A possible explanation is that unless reducing income inequality is the specific objective, some individuals are left out, since they are not the target of any other social policy (e.g., old age, disability, family).

As a policy implication, these findings suggest, in general, to take into account not only the dimension, but also the composition of social expenditure.

The paper is structured as follows. The next section introduces the data and the framework of the analysis. We proceed by describing the outcome indicators adopted for each welfare area. Then, we introduce the method used for calculating the performance index and the data concerning net social expenditure. Finally, we analyse the link between social performance and the composition of social spending. The last section summarizes the main results of the analysis.

\section{DATA AND METHODOLOGICAL FRAMEWORK}

In the following analysis, we use the OECD Social Expenditure and Eurostat databases (2013) regarding the expenditure side of the social systems in 22 European countries (see the Appendix for a detailed description of the sources of data).

Following Adema et al. $(1996,2011,2014)$ and in contrast to the prevailing literature, the total public expenditure allocated to social purposes is considered also in net terms, that is, net of national fiscal measures as tax levies and benefits, thus representing the net - albeit aggregate - benefit that social policies provide for beneficiaries (net public social expenditure in the SOCX Database). In this sense, it represents a more appropriate indicator of the intensity of public intervention in the social sector.

Besides the aggregate item, in our analysis, we also consider data for each of the seven subsectors (branches) considered in the database (family, health, labour market, the elderly, the unemployed, the disabled, and income maintenance).

According to the welfare literature (see, among others, Bertola et al. 2001), welfare policies aim at three main goals: combating social exclusion through the maintenance of a certain standard of living; increasing the remuneration for the participation in the labour market through income support for vulnerable groups (the elderly, the unemployed, and the disabled); and reducing income inequality. Therefore, we also aggregate the items of each branch according to their prevailing goal ${ }^{2}$.

Where necessary, for the purposes of international comparison, monetary variables are expressed in purchasing power parity (PPP) terms (US dollars).

\section{THE PERFORMANCE OF THE SOCIAL SECTOR: OUTPUT INDICATORS}

In this section, we define the indicators used to construct our social protection performance index (SPPI). The concept of performance is a multidimensional concept related to both the efficiency and the effectiveness of social policies, which are themselves dependent on many factors and public policies. In this framework, we use the term performance to indicate the output achieved in different social areas. Considering the seven sub-sectors of social expenditure (family, health, labour market, elderly, disabled, unemployment, inequality), one can distinguish the following outcome indicators.

- Maternal employment and net disposable family income for the family sector. Family policies are mainly oriented towards reconciling work and family life, and regard the provision of educational and care services for early childhood, parental leave and home care for children or the elderly. The main purpose may therefore be identified with encouraging a greater women's participation in the labour market. A further line of intervention regards the granting of tax benefits (deductions and tax credits) or monetary transfers to families with children to support their income level and, ultimately, in order not to discourage births. As indicators, we have therefore used the maternal employment rate and simulated the net disposable income of a 'typical' family, consisting of two children and two working parents with, respectively, a gross income from employment equal to 100 percent and 67 percent of the average income from employment in their country of residence. The net disposable income is calculated by subtracting the income tax (considering deductions or tax credits) and social contributions from gross taxable income (adjusted for deductions) and adding monetary benefits. For the simulation analysis the OECD's tax-benefit calculator model (available at the following link: http://www.oecd.org/els/soc/benefitsandwagestax-benefitcalculator.htm) was used.

2 See Figure 1. 
- Life-expectancy for the health sector. According to the prevailing literature (Tanzi and Schuknecht, 2000, and Afonso et al.,2005, 2006), we use life-expectancy at birth as the performance indicator of health policies.

- The unemployment rate, to assess the performance of active labour market policies, that is, all those initiatives (such as training, work-related education, apprenticeships, careers guidance tools, etc.) designed to promote employment and work placement for the labour market. To consider various categories of workers, in addition to the overall unemployment rate, we have considered unemployment rates for other two aggregates that are often the object of national welfare policies: the female unemployment rate, to which reference is frequently made in the European recommendations, and the youth unemployment rate (based on the number of people aged 15-24 out of work in relation to the youth workforce) which has been especially affected by the economic crisis that has hit the world economy since 2007.

- The net replacement rate, that is, the proportion of labour income (net of fiscal measures) that the national welfare systems respectively guarantee to the elderly and the unemployed after their exit from the labour market. For each of these categories, the indicator that we have identified is the average amount of available resources (that is, net of fiscal measures as direct taxation, resulting from social transfers, indirect taxation of consumption by recipients of transfers and tax benefits for social welfare purposes) which the various national welfare systems guarantee to them ${ }^{3}$. For the elderly, we have used the net replacement rate relating to compulsory pension schemes, which represents the percentage of individual income, net of contributions and taxes, that the pension system guarantees after exiting the job market. Formally, this is the ratio of the net pension to the labour income net of tax. Three levels of labour income were considered: 50 percent, 100 percent and 150 percent of national average labour income. From a methodological point of view, we repeat the same simulation analysis to calculate the net replacement rate of unemployment benefits during the first year of unemployment, which represents the proportion of net labour income replaced by the net benefits received in the event of unemployment. The latter, in turn, depend on both labour income and the recipient's family situation. Therefore, two income categories were considered (67 percent and 100 percent of national average labour income) and, within each of these, six types of family: three typical families (single parent, single-earner households and families with both partners in employment) without children and three families of the same types with two underage children.

- The monetary benefits for the disabled, represented by the transfer that on an average, the national governments allocate in the form of disability pensions or monetary transfers to pay medical expenses and for care and assistance.

- The Gini index calculated based on after-tax-and-transfers disposable income for income inequality.

- The poverty index (calculated as the percentage of households with equivalised disposable household incomes at least 60 percent lower than the median national income as reported in OECD Income distribution and poverty database) is considered as an indicator of the effectiveness of social policies aimed at ensuring a given standard of living.

So, for the seven expenditure subsectors, we totally consider eight sectoral indicators of social intervention: family, health, active labour market policies, old age, disabled, unemployment, poverty and income support. These indicators can be reconnected to the above mentioned general goals, as illustrated in FIGURE 1.

\section{THE SOCIAL PROTECTION PERFORMANCE INDEX}

The next step of the analysis consists in calculating a synthetic performance index. For this purpose, we normalize the values of each outcome's indicators identified in the previous section within the group of the 22 countries considered.

Our sectoral performance index for the $i^{\text {th }}$ country and $j^{\text {th }}$ sector of social policy at time $t$ is thus given by:

$0 \leq P_{i, j, t}=\frac{x_{i, j, t}-x_{\min , \mathrm{j} \mathrm{t}}}{x_{\text {max }, \mathrm{j} \mathrm{t}}-x_{\min , \mathrm{j} \mathrm{t}}} \leq 1 \quad i=1,2 \ldots 22 j=1,2 \ldots 8$

where $x_{i, j, t}$ is the value of the indicator for social sector $j$ in country $i$ at time $t$, while $x_{\text {min,j,t }}$ and $x_{\text {max } j, t}$ represent, respectively, the minimum and maximum values for the same indicator within the group of the 22 countries under consideration. Therefore, the

3 For primary data on the net family income and the net replacement rates for elderly and unemployed, see the Appendix (Tables A2, A3, A4 and A5). 
Fig. 1: Output Indicators for Social Policies.

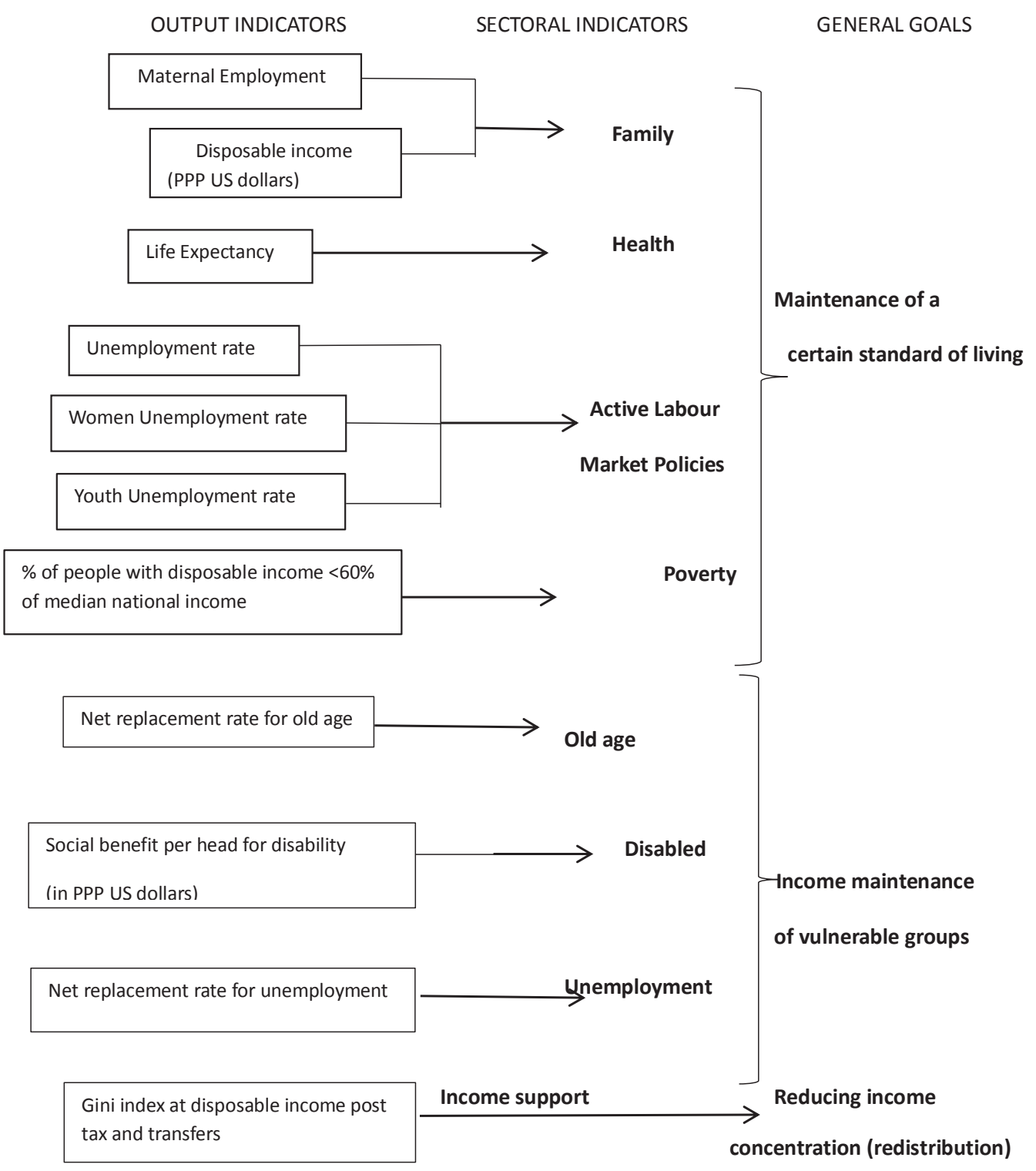

performance index ranges between 0 and 1 , and enables a comparison within the group of countries under consideration. $P_{i, j, t}=0$ indicates the case in which the $i^{\text {th }}$ country exhibits the worst performance in the $j^{\text {th }}$ sector at time $t$; conversely, $P_{i, j, t}=1$ represents the best outcome in the $j^{\text {th }}$ sector at time $t$ for the $i^{\text {th }}$ country.

To ensure that the highest values of the indicator are representative of the best performances, we have used the complement to one of the unemployment rate (in the three measures considered), the poverty index and the Gini index. In these cases, it is in fact clear that higher values of the index would indicate a high gap in the unemployment rate, the poverty index and the income concentration index compared with the respective minimum values, indicating worse - and not better - performances for the country concerned.

The complements to one of these three outcome variables are interpretable as the employment rate, a welfare index representative of the percentage of households with disposable income of over 60 percent of the median disposable income, and an index of equidistribution of disposable income, respectively. 
For the sectors of social expenditure associated with several outcome indicators (for example, family, the elderly, unemployment, labour market and redistribution), we consider their average value following the methodology used in calculating the Human Development Indices. ${ }^{4}$ Finally, the aggregate indicator for the whole area of the social sector was obtained by adding together the individual partial indicators in accordance with the existing literature (Tanzi et al. 2000, 2006). For country $i$ at time $t$, we thus have:

$$
S P P I_{i, t}=\sum_{j=1}^{8} P_{i, j, t}
$$

The final values are characterized by a high degree of heterogeneity within the group of countries considered, ranging from 1.96 (Greece) to 6.34 (Norway). Higher indicators (greater than the median value 4.43) are associated with the Nordic countries (Norway, Denmark, the Netherlands, Finland and Sweden) and Luxembourg, Austria, France, Germany, Belgium and Slovenia.

Differently from Boeri (2002), Sapir (2005) and Caruana (2010), the Anglo-Saxon countries do not outperform the Mediterranean ones. As for the Eastern countries, differently from Caruana (2010), the Czech Republic and Slovenia do not outperform the Nordic countries, ranking with the other central countries; Hungary is slightly above and Poland below the Mediterranean countries (with the exception of Greece). This new evidence, besides the different period under consideration, stems from the measure of performance that we adopt, based on the output of a set of social policy areas that is wider than those adopted in the above-mentioned literature which proposes sectoral effectiveness analyses (labour market, poverty, redistribution, old age) or a more limited set of spending sectors. For instance, the lag of the Mediterranean countries with respect to the Anglo-Saxon countries in the area 'unemployment' is compensated by a better performance in the fields of 'health' (and '“the elderly', as for the United Kingdom). Consequently, we believe that a general performance index can better assess the overall effect of social protection on social welfare.

The disaggregated analysis of the index also shows diversity in its composition among countries (FIGURE 2). Performance levels of the 'family', 'health', 'unemployment', 'income inequality' and 'poverty' sectors are higher in the Nordic countries (Norway, Denmark, Sweden, the Netherlands) and in some continental countries, notably Luxembourg. In the Mediterranean countries, in contrast, the better-performing components are represented by 'health' and 'the elderly', while markedly poor performances are highlighted by the context indicators relating to the fight against poverty and to policies aimed at reducing income inequality. AngloSaxon countries perform well in the unemployment and poverty sectors.

\section{VARIABILITY IN THE PERFORMANCE OF THE SOCIAL SECTOR}

The performance index of the social sector is thus characterized by a certain degree of variability in the context of the European countries considered. What might account for such a variability in performance? Are higher levels of performance necessarily associated with higher levels of expenditure?

At first sight, the level of expenditure appears to be the explanatory variable. High values of the performance index $(\geq 5)$ are seen in the Nordic countries, which typically have generous social policies, while markedly lower values $(\leq 3)$ are associated with the Mediterranean, Eastern and Anglo-Saxon countries, which are traditionally characterized by a lower level of social expenditure. The correlation between total gross social expenditure (also including private measures implemented in the social sector, which however have a minimal impact on national social policies, albeit higher in the Nordic countries: the highest values are observed in the Netherlands where private social expenditure in 2013 was 21 percent of total social expenditure) and the performance index, in fact, is positive, and linear interpolation accounts for around 20 percent of the phenomenon (see FIGURE 3).

In recent years, however, several socio-economic factors have had an impact on the national social policies, modifying the level of expenditure in a non-uniform way. Between 2000 and 2011 public social expenditure increased, on an average, by 13.2 percent in relation to the GDP in the Nordic countries (Sweden, Finland and Norway) and by 35 percent in the Mediterranean countries (Greece, Italy, Portugal and Spain), thus reducing the discrepancies, which nonetheless persisted.

This phenomenon is even more evident if we consider the net public social expenditure, that is, the social spending net not only of measures undertaken by the private sector but also of the fiscal measures that the government imposes on it (in three forms: direct

4 Methodological notes available at the following link. http://hdr.undp.org/en/content/calculating-indices. 
Tab. 1: The Social Protection Performance Index (2013).

\begin{tabular}{|c|c|c|c|c|c|c|c|c|c|}
\hline & Family & Health & $\begin{array}{l}\text { Labour } \\
\text { market }\end{array}$ & Old Age & Unemployment & Disability & $\begin{array}{l}\text { Income inequality } \\
\text { (Gini index) }\end{array}$ & Poverty & $\begin{array}{l}\text { Final } \\
\text { Index } 2013 \\
\end{array}$ \\
\hline \multicolumn{10}{|l|}{ Country } \\
\hline Austria & 0,71546 & 0,73333 & 0,57357 & 0,78301 & 0,95459 & 0,27485 & 0,69231 & 0,71852 & 5,44563 \\
\hline Belgium & 0,6224 & 0,66667 & 0,77395 & 0,3154 & 0,75814 & 0,2922 & 0,79487 & 0,44444 & 4,66809 \\
\hline $\begin{array}{l}\text { Czech } \\
\text { Republic }\end{array}$ & 0,16766 & 0,34667 & 0,67284 & 0,4456 & 0,81737 & 0,02246 & 0,84615 & 0,9037 & 4,22247 \\
\hline Denmark & 0,75796 & 0,62667 & 0,76844 & 0,75061 & 0,88648 & 0,67877 & 0,91453 & 0,88148 & 6,26494 \\
\hline Estonia & 0,21755 & 0,21333 & 0,48165 & 0,35513 & 0,80454 & 0,05139 & 0 & 0 & 2,12361 \\
\hline Finland & 0,62046 & 0,72 & 0,58828 & 0,3533 & 0,8075 & 0,46712 & 0,84615 & 0,71852 & 5,12133 \\
\hline France & 0,57597 & 0,88 & 0,66917 & 0,41993 & 0,72162 & 0,21753 & 0,57265 & 0,71111 & 4,76798 \\
\hline Germany & 0,60792 & 0,69333 & 0,69123 & 0,17665 & 0,97927 & 0,30079 & 0,58974 & 0,63704 & 4,67597 \\
\hline Greece & 0,1852 & 0,76 & 0,06802 & 0,54095 & 0 & 0,01775 & 0,15385 & 0,23704 & 1,96281 \\
\hline Hungary & 0,01661 & 0 & 0,53313 & 0,89364 & 0,69398 & 0 & 0,61538 & 0,51111 & 3,26386 \\
\hline Ireland & 0,34385 & 0,72 & 0,44121 & 0,09413 & 0,65647 & 0,06867 & 0,44444 & 0,59259 & 3,36137 \\
\hline Italy & 0,23254 & 0,94667 & 0,69307 & 0,66748 & 0,51234 & 0,09884 & 0,30769 & 0,31111 & 3,76974 \\
\hline Luxembourg & 0,82886 & 0,82667 & 1 & 0,51223 & 0,87858 & 0,79827 & 0,68376 & 0,60741 & 6,13577 \\
\hline Netherlands & 0,79851 & 0,76 & 0,75925 & 1 & 0,91412 & 0,32221 & 0,69231 & 0,6963 & 5,94269 \\
\hline Norway & 0,73652 & 0,81333 & 0,70593 & 0,40159 & 1 & 1 & 0,93162 & 0,75556 & 6,34456 \\
\hline Poland & 0,22776 & 0,18667 & 0,2923 & 0,24694 & 0,67522 & 0,01699 & 0,52137 & 0,48889 & 2,65613 \\
\hline Portugal & 0,44781 & 0,68 & 0,88242 & 0,45477 & 0,45508 & $0,0755^{8}$ & 0,16239 & 0,3037 & 3,46175 \\
\hline $\begin{array}{l}\text { Slovak } \\
\text { Republic } \\
\end{array}$ & 0,04866 & 0,10667 & 0,64343 & 0,72555 & 0,53998 & 0,0405 & 0,78632 & 0,76296 & 3,65407 \\
\hline Slovenia & 0,55499 & 0,62667 & 0,8622 & 0,29279 & 0,73445 & 0,02904 & 0,90598 & 0,62222 & 4,62833 \\
\hline Spain & 0,30206 & 1 & 0,69307 & 0,61064 & 0,08687 & 0,0932 & 0,12821 & 0,08889 & 3,00292 \\
\hline Sweden & 0,78848 & 0,84 & 0,44305 & 0,35147 & 0,76703 & 0,55008 & 0,68376 & 0,54815 & 4,97201 \\
\hline $\begin{array}{l}\text { United } \\
\text { Kingdom }\end{array}$ & 0,56318 & 0,72 & 0 & 0 & 0,80849 & 0,10657 & 0,02564 & 0,4963 & 2,72018 \\
\hline
\end{tabular}

Source: Our elaborations on OECD (SOCX Database) and Eurostat (Social Protection Database) data.

Fig. 2: Composition of the Social Protection Performance Index by sector (2013). Composition of the SPPI by sector (2013)

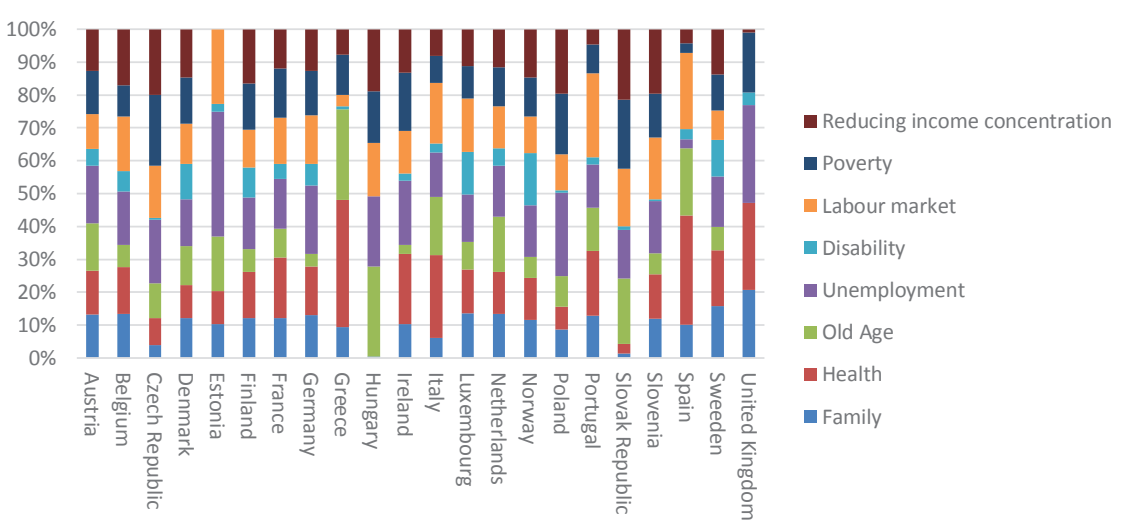

Source: Our elaborations on OECD (SOCX Database) and Eurostat (Social Protection Database) data. 
Fig. 3: Total Gross Social Expenditure/GDP and Social Protection Performance Index (2013).

\section{Total gross Social Expenditure and SPPI}

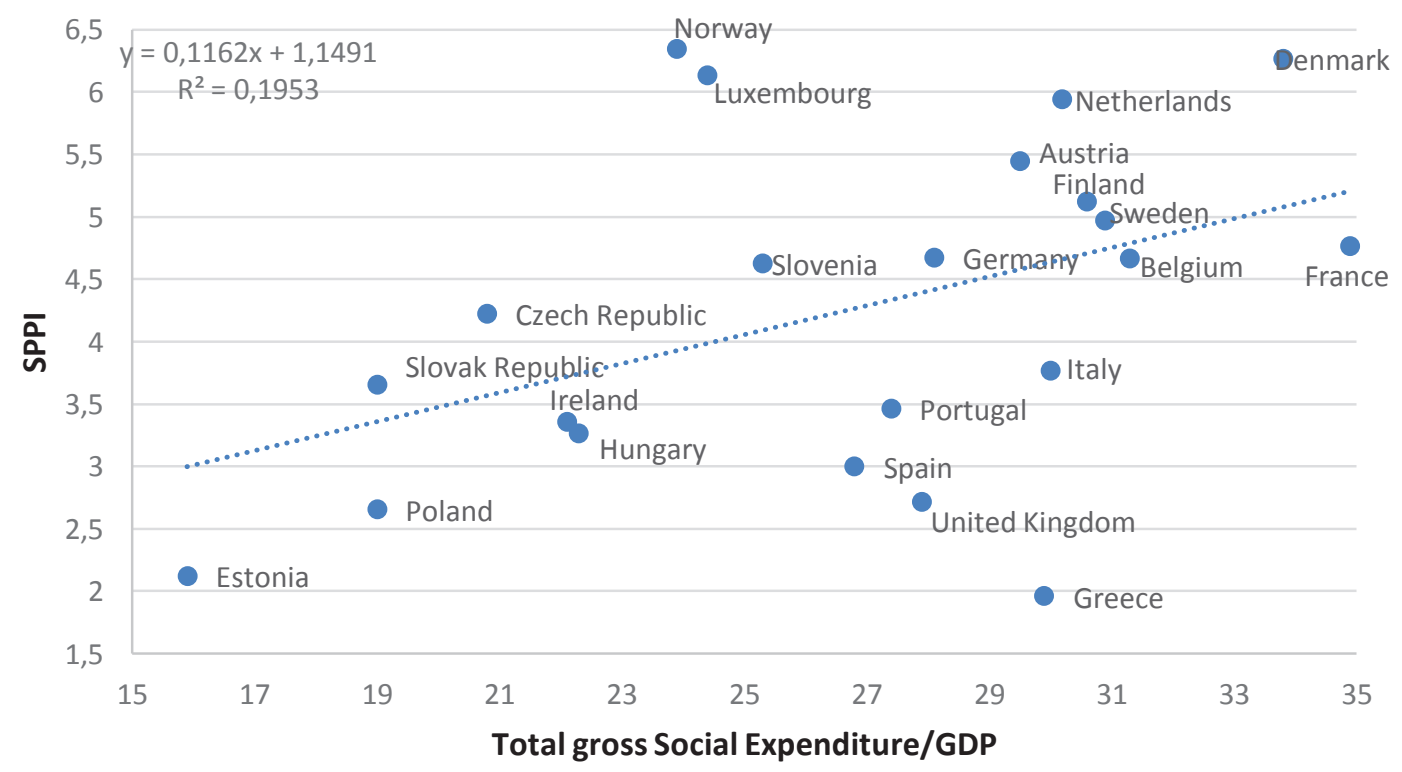

Source: Our elaborations on OECD (SOCX Database) and Eurostat (Social Protection Database) data.

taxation of income resulting from social transfers, indirect taxation on consumption by recipients of transfers, and tax benefits for social welfare purposes).

In the Nordic countries (Finland, Denmark, Luxembourg, Norway and Sweden), fiscal measures (taxation net of tax benefits granted) reduce the gross social expenditure by around 20 percent. More limited measures characterize the other countries.

The result is a reduced variability in net levels of expenditure (from 18.2 for total gross expenditure to 9.3 for net public expenditure) and a re-ranking of countries, mainly placing all Nordic countries (except for Norway) and a few continental ones (Austria and Luxembourg) in lower positions. By comparing the performance indicator with net social expenditure in relation to GDP (FIGURE 4), a high level of variability of the index emerges corresponding to the given levels of expenditure, as does the absence of a clear general trend, while clearer correlations can be observed within the subgroups of countries.

FIGURE 4 shows that most of the countries considered rank between the first and the third quartile of the net public social expenditure (with values, respectively, of 23.5 and 19.7), while exhibiting an extremely high degree of heterogeneity in terms of the performance index, as, for example, in the cases of Spain, Portugal, Greece, Germany and Denmark. This variability in performance does not appear to be attributable to private social expenditure. In Denmark, it accounts for around 5 percent of total social expenditure, while in Mediterranean countries as well as in Germany private involvement in the social sector is much lower.

We may investigate the relationship that exists between the two variables considered (performance index and net public social expenditure/GDP) by classifying the countries into subgroups distinguished by different levels of performance. What emerges is that, for the countries lying at the extremes of the distribution according to the performance index (namely the Mediterranean and the Nordic countries respectively belonging to the first quartile and to the interquartile difference Q4-Q3), there is not a strong positive correlation with expenditure.

Considering the countries placed between the third and the first quartile of the index (with corresponding values of 3.26 and 5.12), a positive correlation (with a value of 0.56 ) exists between the net public expenditure and the performance of the social sector (FIGURE 5).

In contrast, the correlation between expenditure and performance is markedly clearer (0.84) if we consider the cluster of Eastern countries, characterized by a level of net social public expenditure with respect to GDP lower than the average value (20.9). For this set of countries, differences in performance levels seem to be associated with expenditure levels (FIGURE 6) 
Fig. 4: The Social Performance Protection Index and Net Public Social Expenditure (2013).

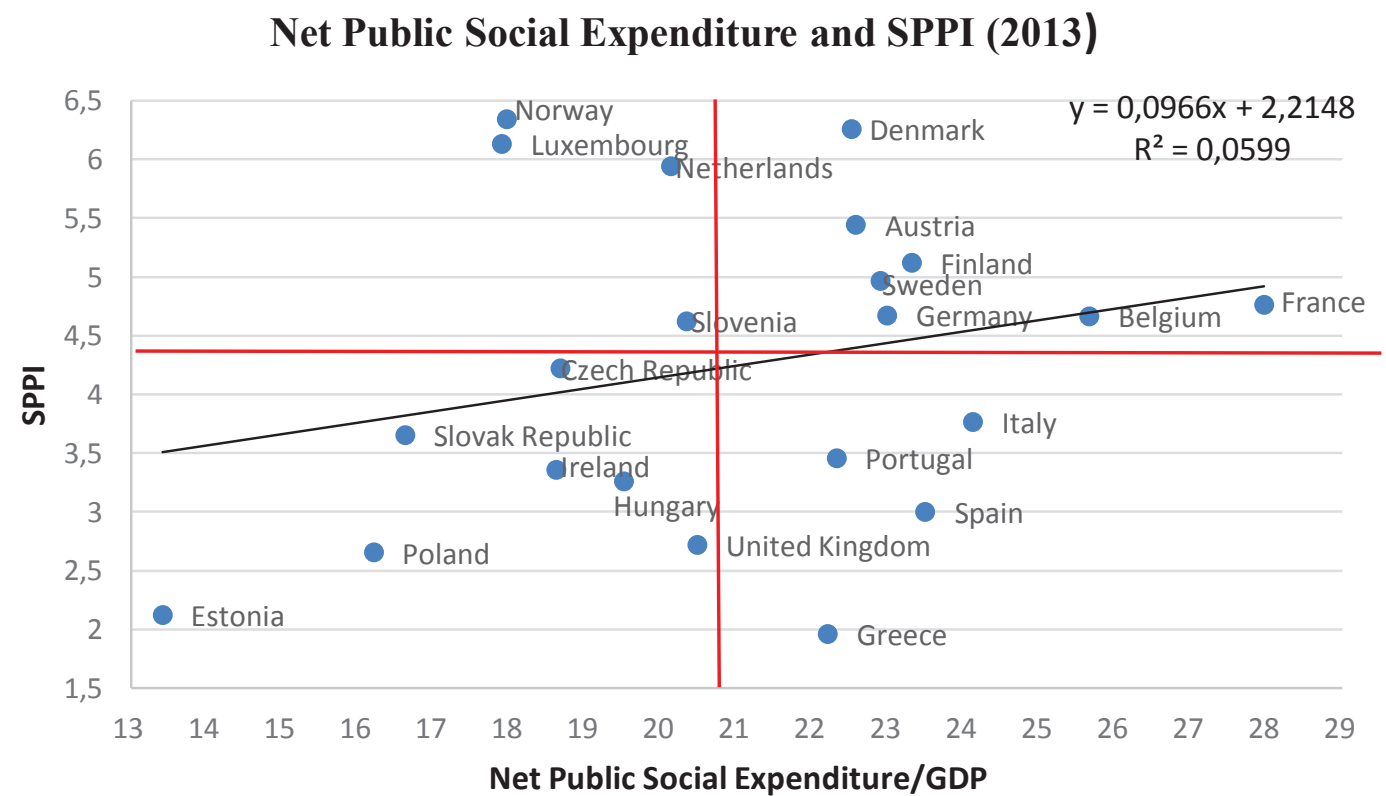

Source: Our elaborations on OECD (SOCX Database) and Eurostat (Social Protection Database) data.

Fig. 5: Social Protection Performance Index and Net Public Social Expenditure. Subgroup of countries (2013).

\section{Net Social Pubblic Expenditure and SPPI (interquartilic difference $Q_{3}-Q_{1}$ )}

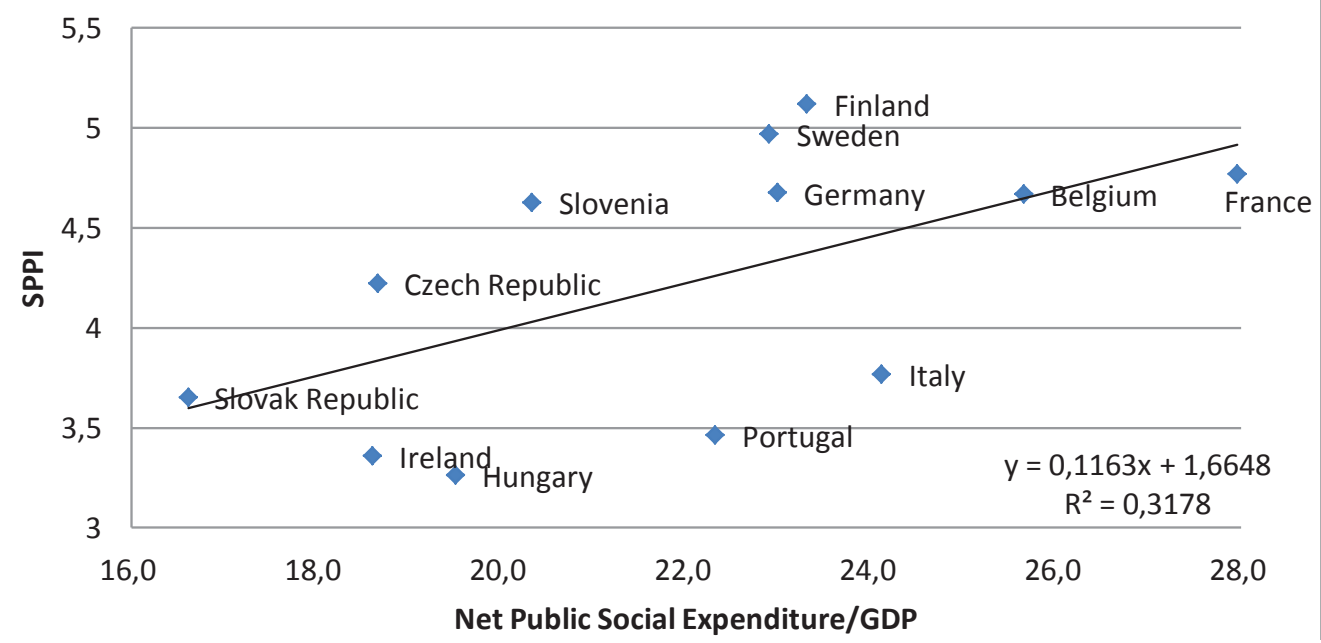

Source: Our elaborations on OECD (SOCX Database) and Eurostat (Social Protection Database) data. 
Fig. 6: Social Protection Performance Index and Net Social Public Expenditure. Eastern countries (2013).

\section{Net Social Public Expenditure and SPPI : Eastern countries}

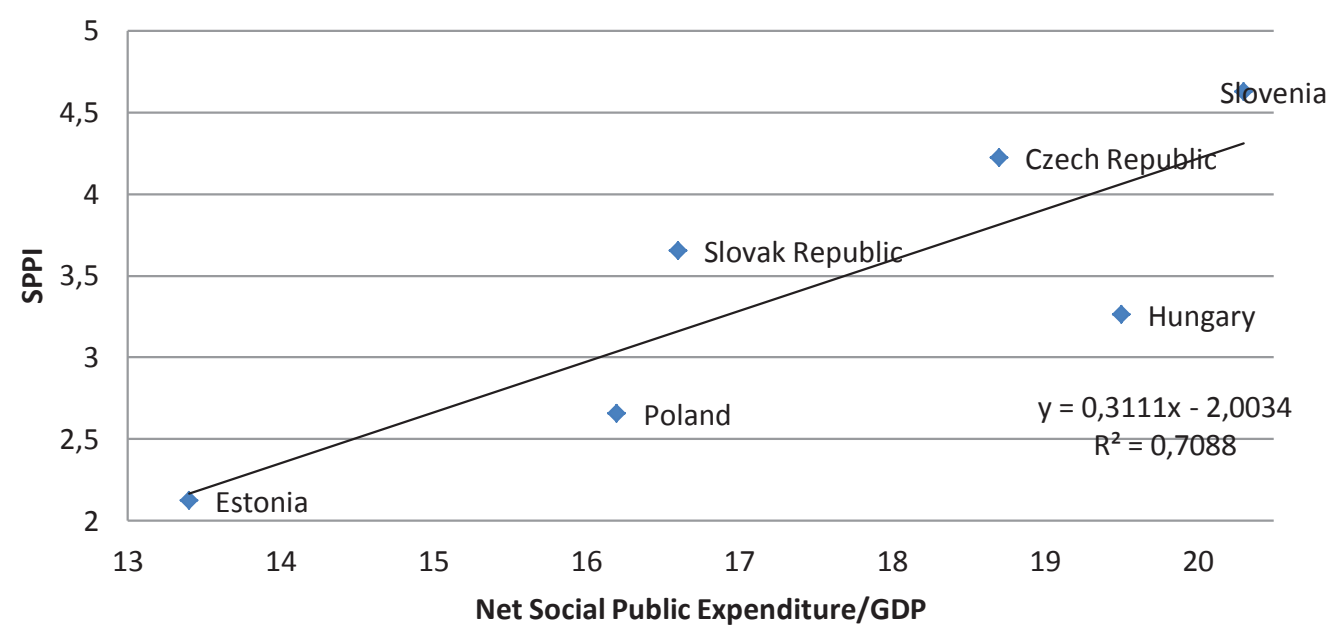

Source: Our elaborations on OECD (SOCX Database) and Eurostat (Social Protection Database) data.

Tab. 2: Social expenditure by goal (year 2013).

\begin{tabular}{llll} 
\%Gross Social Public Expenditure & Income concentration & Support for vulnerable groups & Standard of living \\
\hline Austria & 0,415871 & 0,542763 & 0,041366 \\
\hline Belgium & 0,446187 & 0,508832 & 0,04498 \\
\hline Czech Republic & 0,435319 & 0,042495 \\
\hline Denmark & 0,541717 & 0,522185 & 0,070786 \\
\hline Finland & 0,425887 & 0,387497 & 0,050845 \\
\hline France & 0,403169 & 0,523268 & 0,058045 \\
\hline Germany & 0,461669 & 0,538786 & 0,03514 \\
\hline Ireland & 0,481882 & 0,503191 & 0,056108 \\
\hline Italy & 0,332541 & 0,46201 & 0,029875 \\
\hline Netherlands & 0,544255 & 0,075965 \\
\hline Norway & 0,575327 & 0,379781 & 0,042224 \\
\hline Portugal & 0,334706 & 0,382449 & 0,017139 \\
\hline Slovak Republic & 0,483621 & 0,648155 & 0,030658 \\
\hline Spain & 0,369254 & 0,485721 & 0,026484 \\
\hline Sweden & 0,547214 & 0,604262 & 0,045279
\end{tabular}

Source: Our elaboration of OECD data (SOCX database).

For Standard of living: social expenditure for the following programs: old age (other cash benefits), family (other cash benefits), housing, other social policy areas.

For Support for vulnerable groups social expenditure for the following programs: old age (pensions, early retirement pensions), survivors (pensions, other cash benefits), incapacity related (pensions and paid sick leave for occupational injury and desease), family (maternity and parental leave), active labour market, unemployment).

For income concentration social expenditure for the following programs: old age (residential care/home help services, other benefits in kind), survivors (other benefits in kind), incapacity related (disability pensions, other cash benefits, residential care/home help services, rehabilitation services, other benefits in kind), family (allowances, early childhood education and care, home care/accommodation, other benefits in kind). 
Nevertheless, the overall correlation between performance and total social expenditure appears rather low; however, differences in performance levels can be associated with another feature of the welfare systems.

As mentioned above, the welfare policies can be referred to three general goals: maintenance of a certain standard of living; income support for vulnerable groups; and reducing income concentration. We have thus tested whether the social expenditure's composition by this "three goals classification" may explain performance differences. To do this, we have grouped the previous sub-sectors into three main expenditure's macro-sectors corresponding to the three main objectives of the welfare policies. In practice, it is difficult to assign each item of expenditure to one single goal, as instruments may target more than one of them at the same time. Therefore, we have partitioned social expenditure according to its main goal for the European countries under consideration (TABLE 2).

The data indicate that the main objective relates to income support for vulnerable groups in Austria, Belgium, the Czech Republic, Finland, France, Germany, Italy, Portugal and Spain. The reduction of income concentration prevails in Denmark, Iceland, the Netherlands, Norway and Sweden (countries traditionally characterized by a low level of income concentration), while in Ireland and the UK, the fight against social exclusion is relatively more important, exceeding 10 percent of the overall expenditure.

Then, we have implemented a cluster analysis using the composition of expenditure by the three goals (standard of living; income support and reducing income concentration). Variables are scaled by their standard deviation; the Euclidean measurement of distance is used, while the aggregation method adopted is the average link method. The result is that countries can be divided into five groups: the first one comprises the UK on its own; the second Denmark, Sweden, Norway, the Netherlands and Ireland; the third the Czech Republic and Slovakia; the fourth Austria, Germany, Belgium, Finland and France; and the fifth Italy, Spain and Portugal. This grouping of countries corresponds to the traditional classification of welfare systems; the only exceptions are Austria, that belongs to the central group but displays a level of the performance index similar to the Nordic countries, and Ireland, which belongs to the Nordic group though displaying a low performance level (Ireland is, however, a sort of outlier, on the 'edge' of the group of central European countries). This grouping of countries also fits the ranking obtained according to the performance index (Antonelli and De Bonis 2016).

In particular, countries with a higher performance index are characterized by a higher share of expenditure aimed at reducing income concentration. In fact, the Nordic countries are characterized by higher levels of both the index and the share of social spending aimed at reducing income concentration, the central European countries by intermediate levels, and the southern European countries and the UK by low levels.

\section{CONCLUSIONS}

We have measured the effectiveness of the European social policies through a newly developed performance index, based on the output of all the main sectors of social policy; this results in a different ranking of countries with respect to those found in the existing literature.

The paper also shows that the variability of national performances is high and that this cannot be explained only by expenditure levels. Essentially similar levels of net social expenditure are often accompanied by a high degree of variability in performance compare, for instance, Greece, Portugal, Austria and Denmark. Furthermore, this variability of performance does not appear to be attributable to private intervention in the social sector, which is in any case limited compared with public policies in all countries. In the paper, we propose an avenue for future research: considering the composition of social expenditure as a determinant of its performance. Actually, the performance of European countries seems to relate to both quantitative and qualitative dimensions of public intervention: countries with a high public social expenditure/GDP ratio achieve a high performance index if the share of spending destined to reduce inequality in income distribution is high.

As a policy implication for countries with low levels of social spending, the paper suggests a modification of the composition of social expenditure rather than a tout-court expansionary policy. 


\section{REFERENCES}

Adema, W., Einerhand, M., Eklind, B., Lotz, J. \& Pearson, M. (1996). Net public social expenditure. OECD Labor Market and Social Policy Occasional Papers, 19.

Adema, W., Fron, P. \& Ladaique, M. (2011). Is the European Welfare State Really More Expensive? Indicators on Social Spending, 1980-2012. OECD Social, Employment and Migration Working Papers, No. 124, OECD Publishing. http://dx.doi.org/10.1787/5kg2d2d4pbfo-en.

Adema, W., From, P. \& Ladaique, M. (2014). How Much Do OECD Countries Spend on Social Protection and How Redistributive are their Tax/benefit Systems. International Social Security Review, 67 (1), 1-25.

Afonso, A., Schuknecht, L. \& Tanzi, V. (2005). Public Sector Efficiency: An International Comparison. Public Choice, 123, 321-347.

Afonso, A., Schuknecht, L. \& Tanzi, V. (2006). Public Sector Efficiency: Evidence from New EU Member States and Emerging Markets. ECB Working Paper, No. 581.

Antonelli, M.A., \& De Bonis, V. (2016). Clustering European welfare states through a performanceindex'. Public Finance Research Papers, No.18 http://www.digef.uniroma1.it/pubblicazioni/istituto-economia-efinanza/public-finance-research-papers

Antonelli, M. A. \& De Bonis, V. (2017). Social Welfare, Spending and Redistribution: A Comparative Analysis of 22 European Countries. Modern Economy, 8, 1291-1313.

Arts, W. \& Gelissen, J. (2002). Three worlds of welfare capitalism or more? A state-of-the-art report. Journal of European Social Policy, 12(2), 137-158.

Bertola, G., Jimeno, J.F., Marimon, R. \& Pissarides, C. (2001). EU Welfare Systems and Labor Markets: Diverse in the past, integrated in the future?' in Bertola, G, Boeri, T. \& Nicoletti, G. (eds.) Welfare and Employment in a United Europe, MIT Press.

Boeri, T. (2002). Let Social Policy Models Compete and Europe Will Win, paper presented at a

conference hosted by the Kennedy School of Government, Harvard University, 11-12 April.

Bouget, D. (2003). Convergence in the Social Welfare Systems in Europe: From Goal to Reality. Social Policy and Administration, 37(6), 674-693.

Caminada, K., Goudswaard, K. \& van Vliet, O. (2010). Patterns of welfare state indicators in the EU: is there convergence? Journal of Common Market Studies, 48( 3), 529-556.

Caruana, C. (2010). Measuring the Efficiency and Effectiveness of the Welfare State: A Comparative Study of the EU-27 Member States. Bank of Valletta Review, 42, 75-106.
Esping-Andersen, G. (1990). The Three Worlds of Welfare Capitalism, Princeton University Press.

Ferrera, M. (1996). The 'Southern Model' of Welfare in Social Europe'. Journal of European Social Policy, 6(1), 17-37.

Ferrera, M., Hemerijck, A. \& Rhodes, M. (2000). The future of social Europe, Oeiras (Port.), Celta Editoria.

Ferrera, M. (2009). National welfare states and European integration: in search of a virtuous nesting'. Journal of Common Market Studies, 47(2), 219-233.

Ferrera, M. (2012). Le politiche sociali, II Mulino, Bologna.

Ferrera, M., Fargion, V. \& Jessoula, M. (2012). Alle radici del Welfare all'italiana. Origini e futuro di un modello sociale squilibrato, Marsilio editore, Venezia.

Goodin, R., Headey, B., Muffles, R. \& Dirven, H.J. (1999) The real worlds of welfare capitalism, Cambridge University Press.

Hudson, J. \& Kühner, S. (2012). Analyzing the Productive and Protective Dimensions of Welfare: Looking Beyond the OECD'. Social Policy and Administration, 46(1), 35-60.

Joumard, I., Pisu, M. \& Bloch, D. (2012). Tackling income inequality: The role of taxes and transfers. Economic Studies, published online first. http://dx.doi.org/10.1787/eco_studies-2012-5k95xd6l65lt.

Minas, C., Jacobson, D., Antoniou, E. \& McMullan, C. (2014). Welfare regime, welfare pillar and Southern Europe. Journal of European Social Policy, 24(2), 135-149.

Rhodes, M. (1996). Globalization and West European welfare states: a critical review of recent debates. Journal of European Social Policies, 6(4), $705-27$.

Sapir, A. (2005). Globalisation and the reform of European Social Models. Bruegel Policy Brief, 1, 1-8.

Tanzi, V. \& Schuknecht, L. (2000). Public spending in the $20^{\text {th }}$ century. A global perspective Cambridge University Press.

Titmuss, R. (1974). Social policy: an introduction, Allen and Unwin ed., London.

United Nations, Human Development Index. Available at http://hdr. undp.org/en/content/human-development-index-hdi.

Van Vliet, O. (2010). Divergence within convergence: Europeanization of social and labour market policies. European Integration, 32(3), 269-290.

Zoli, M. (2004). I sistemi di welfare state nei paesi dell'Unione Europea, LLEE Working Document, No.1. 


\section{APPENDIX}

Tab. A1: Source of data.

\begin{tabular}{ll}
\hline Variables & Source of data \\
\hline Maternal Employment & OECD Family database \\
\hline Net Disposable Family Income & OECD Tax-Benefits Calculator Model \\
\hline Life Expectancy & OECD Family database \\
\hline Unemployment Rates & OECD Labour Market Statistics \\
\hline Net Replacement Rate for the elderly & OECD Pensions Statistics database \\
\hline Net Replacement Rate for the unemployed & OECD Benefits and Wages Statistics \\
\hline Monetary Benefits for disabled & Eurostat Social Protection database \\
\hline Gini Index & OECD Income Distribution and Poverty database \\
\hline Poverty & OECD Income Distribution and Poverty database \\
\hline
\end{tabular}

Tab. A2: Net Family Income (2013).

\begin{tabular}{ll}
\hline Countries & Net Family income in PPP (US dollars) 2013 \\
\hline Austria & 64998,75 \\
\hline Belgium & 62648,28 \\
\hline Czech Republic & 32836,91 \\
\hline Denmark & 58836,54 \\
\hline Estonia & 30900,19 \\
\hline Finland & 59222,34 \\
\hline France & 57993,89 \\
\hline Germany & 66490,35 \\
\hline Greece & 49334,96 \\
\hline Hungary & 29814,12 \\
\hline Ireland & 60947,56 \\
\hline Italy & 50506,70 \\
\hline Luxembourg & 84729,00 \\
\hline Netherlands & 71318,07 \\
\hline Norway & 72517,29 \\
\hline Poland & 29406,64 \\
\hline Portugal & 39433,96 \\
\hline Slovak Republic & 28512,05 \\
\hline Slovenia & 37712,85 \\
\hline Spain & 52286,35 \\
\hline Sweden & 60947,32 \\
\hline United Kingdom & 68063,40 \\
\hline
\end{tabular}

Source: elaboration on OECD tax-benefit calculator data 
Tab. A3: Net Replacement Rate for Pensions (2013).

\begin{tabular}{|c|c|c|c|}
\hline & \multicolumn{3}{|c|}{ Net Replacement Rate for pensions (2013) } \\
\hline & Low earner $(0,5 \mathrm{AW})$ & Average earner (AW) & High earner $(1,5 \mathrm{AW})$ \\
\hline Austria & 91,2 & 90,2 & 86,2 \\
\hline Belgium & 80,7 & 62,1 & 48,3 \\
\hline Czech Republic & 97,8 & 63,8 & 50,8 \\
\hline Denmark & 117,5 & 77,4 & 67,4 \\
\hline Estonia & 79,7 & 62,4 & 55,5 \\
\hline Finland & 71,3 & 62,8 & 63,2 \\
\hline France & 75,9 & 71,4 & 60,9 \\
\hline Germany & 55,2 & 57,1 & 56,1 \\
\hline Greece & 92,5 & 70,5 & 65 \\
\hline Hungary & 94,4 & 95,2 & 96,1 \\
\hline Ireland & 75,5 & 44,8 & 34,6 \\
\hline Italy & 83,9 & 81,5 & 83,3 \\
\hline Luxembourg & 87,1 & 69,4 & 66,8 \\
\hline Netherlands & 104,8 & 101,1 & 97,2 \\
\hline Norway & 91,1 & 62,8 & 51,3 \\
\hline Poland & 61,3 & 59,5 & 59,1 \\
\hline Portugal & 77,7 & 67,8 & 68,4 \\
\hline Slovak Republic & 88,1 & 85,4 & 84,7 \\
\hline Slovenia & 63,5 & 63,3 & 60,6 \\
\hline Spain & 79,5 & 80,1 & 79,8 \\
\hline Sweden & 68,8 & 55,3 & 72,9 \\
\hline United Kingdom & 67,2 & 41,8 & 30,5 \\
\hline
\end{tabular}

Source: Pensions at a Glance, OECD Pensions Statistics (database)

Tab. A4: Net replacement rates unemployed: case 1 (67\% AW) (2013).

\begin{tabular}{|c|c|c|c|c|c|c|}
\hline & $67 \%$ of Averag & Nage (AW) & & & & \\
\hline & No children & & & 2 children & & \\
\hline Countries & Single person & $\begin{array}{l}\text { One-earner } \\
\text { married couple }\end{array}$ & $\begin{array}{l}\text { Two-earner } \\
\text { married couple }\end{array}$ & Lone parents & $\begin{array}{l}\text { One-earner } \\
\text { married couple }\end{array}$ & $\begin{array}{l}\text { Two-earner } \\
\text { married couple }\end{array}$ \\
\hline Austria & 55 & 57 & 80 & 71 & 72 & 85 \\
\hline Belgium & 90 & 83 & 84 & 95 & 82 & 85 \\
\hline $\begin{array}{l}\text { Czech } \\
\text { Republic }\end{array}$ & 65 & 65 & 87 & 67 & 67 & 88 \\
\hline Denmark & 84 & 85 & 92 & 89 & 87 & 92 \\
\hline Estonia & 55 & 57 & 77 & 65 & 62 & 79 \\
\hline Finland & 59 & 59 & 80 & 74 & 69 & 84 \\
\hline France & 69 & 65 & 84 & 71 & 68 & 84 \\
\hline Germany & 59 & 59 & 86 & 81 & 83 & 90 \\
\hline Greece & 39 & 40 & 68 & 46 & 46 & 70 \\
\hline Hungary & 68 & 68 & 84 & 76 & 76 & 87 \\
\hline
\end{tabular}


continued Tab. A4: Net replacement rates unemployed: case 1 (67\% AW) (2013).

\begin{tabular}{|c|c|c|c|c|c|c|}
\hline \multirow[b]{3}{*}{ Countries } & \multicolumn{6}{|c|}{$67 \%$ of Average Wage (AW) } \\
\hline & No children & & & 2 children & & \\
\hline & Single person & $\begin{array}{l}\text { One-earner } \\
\text { married couple }\end{array}$ & $\begin{array}{l}\text { Two-earner } \\
\text { married couple }\end{array}$ & Lone parents & $\begin{array}{l}\text { One-earner } \\
\text { married couple }\end{array}$ & $\begin{array}{l}\text { Two-earner } \\
\text { married couple }\end{array}$ \\
\hline Ireland & 50 & 80 & 75 & 50 & 75 & 81 \\
\hline Italy & 72 & 76 & 86 & 81 & 78 & 88 \\
\hline Luxembourg & 83 & 81 & 90 & 90 & 89 & 93 \\
\hline Netherlands & 76 & 77 & 84 & 67 & 81 & 77 \\
\hline Norway & 68 & 69 & 84 & 79 & 73 & 86 \\
\hline Poland & 49 & 50 & 75 & 80 & 56 & 76 \\
\hline Portugal & 75 & 75 & 93 & 79 & 78 & 94 \\
\hline $\begin{array}{l}\text { Slovak } \\
\text { Republic }\end{array}$ & 62 & 58 & 85 & 72 & 57 & 86 \\
\hline Slovenia & 86 & 83 & 93 & 85 & 88 & 96 \\
\hline Spain & 78 & 75 & 89 & 76 & 74 & 88 \\
\hline Sweden & 63 & 63 & 81 & 71 & 67 & 83 \\
\hline $\begin{array}{l}\text { United } \\
\text { Kingdom }\end{array}$ & 20 & 31 & 60 & 47 & 56 & 67 \\
\hline
\end{tabular}

Source: OECD Benefits and wages statistics $h t t p: / / w w w . o e c d . o r g / e l s / b e n e f i t s-a n d$-wages-statistics.htm

Tab. A5: Net replacement rates unemployed: case 2 (100\% AW) (2013).

\begin{tabular}{|c|c|c|c|c|c|c|}
\hline \multirow[b]{3}{*}{ Countries } & \multicolumn{6}{|c|}{$100 \%$ of Average Wage (AW) } \\
\hline & \multicolumn{3}{|c|}{ No children } & \multicolumn{3}{|c|}{2 children } \\
\hline & $\begin{array}{l}\text { Single } \\
\text { person }\end{array}$ & $\begin{array}{l}\text { One-earner } \\
\text { married couple }\end{array}$ & $\begin{array}{l}\text { Two-earner } \\
\text { married couple }\end{array}$ & $\begin{array}{l}\text { Lone } \\
\text { parents }\end{array}$ & $\begin{array}{l}\text { One-earner } \\
\text { married couple }\end{array}$ & $\begin{array}{l}\text { Two-earner } \\
\text { married couple }\end{array}$ \\
\hline Austria & 55 & 56 & 76 & 67 & 68 & 81 \\
\hline Belgium & 67 & 63 & 71 & 74 & 64 & 74 \\
\hline Czech Republic & 65 & 65 & 83 & 70 & 66 & 89 \\
\hline Denmark & 58 & 60 & 75 & 67 & 64 & 76 \\
\hline Estonia & 54 & 56 & 73 & 60 & 61 & 74 \\
\hline Finland & 58 & 58 & 76 & 70 & 65 & 79 \\
\hline France & 67 & 67 & 80 & 71 & 68 & 81 \\
\hline Germany & 59 & 59 & 83 & 71 & 69 & 88 \\
\hline Greece & 28 & 28 & 57 & 33 & 34 & 59 \\
\hline Hungary & 45 & 45 & 67 & 57 & 56 & 72 \\
\hline Ireland & 36 & 57 & 63 & 48 & 67 & 69 \\
\hline Italy & 57 & 60 & 75 & 69 & 69 & 77 \\
\hline Luxembourg & 85 & 82 & 88 & 93 & 89 & 92 \\
\hline Netherlands & 75 & 77 & 83 & 68 & 81 & 78 \\
\hline Norway & 65 & 66 & 79 & 76 & 69 & 81 \\
\hline Poland & 33 & 35 & 60 & 53 & 41 & 62 \\
\hline
\end{tabular}


Continued Tab. A5: Net replacement rates unemployed: case 2 (100\% AW) (2013).

\begin{tabular}{|c|c|c|c|c|c|c|}
\hline \multirow[b]{3}{*}{ Countries } & \multicolumn{6}{|c|}{$100 \%$ of Average Wage (AW) } \\
\hline & \multicolumn{3}{|c|}{ No children } & \multicolumn{3}{|c|}{2 children } \\
\hline & $\begin{array}{l}\text { Single } \\
\text { person }\end{array}$ & $\begin{array}{l}\text { One-earner } \\
\text { married couple }\end{array}$ & $\begin{array}{l}\text { Two-earner } \\
\text { married couple }\end{array}$ & $\begin{array}{l}\text { Lone } \\
\text { parents }\end{array}$ & $\begin{array}{l}\text { One-earner } \\
\text { married couple }\end{array}$ & $\begin{array}{l}\text { Two-earner } \\
\text { married couple }\end{array}$ \\
\hline Portugal & 75 & 75 & 95 & 77 & 77 & 98 \\
\hline Slovak Republic & 65 & 59 & 82 & 93 & 58 & 84 \\
\hline Slovenia & 68 & 67 & 81 & 77 & 72 & 84 \\
\hline Spain & 56 & 56 & 74 & 70 & 70 & 82 \\
\hline Sweden & 44 & 44 & 67 & 53 & 48 & 68 \\
\hline United Kingdom & 14 & 22 & 50 & 40 & 48 & 56 \\
\hline
\end{tabular}

Source: OECD Benefits and wages statistics http://www.oecd.org/els/benefits-and-wages-statistics.htm. 